\title{
Female child presenting with Duchenne muscular dystrophy like phenotype: severe childhood autosomal recessive muscular dystrophy: a rare case report
}

\author{
Shaik M. Rafi*, Sravya S. Sreekantham, Kedarnath R. Tumati
}

Department of Pediatrics, Narayana Medical College, Nellore, Andhra Pradesh, India

Received: 05 October 2018

Accepted: 310 ctober 2018

*Correspondence:

Dr. Shaik M. Rafi,

E-mail: rafi7862010@gmail.com

Copyright: (c) the author(s), publisher and licensee Medip Academy. This is an open-access article distributed under the terms of the Creative Commons Attribution Non-Commercial License, which permits unrestricted non-commercial use, distribution, and reproduction in any medium, provided the original work is properly cited.

\begin{abstract}
Severe Childhood Autosomal Recessive Muscular Dystrophy (SCARMD) is a variant of sarcoglycanopathy resulting from mutation in the sarcoglycan genes. SCARMD is a rare form of muscular dystrophy characterised by severe DMD like phenotype occurring at early ages and affecting boys as well as girls. Here we are reporting a case of 7year old female child born to 3rd degree consanguineous parents presented with proximal muscle weakness beginning in both lower limbs since4 years of age. On thorough clinical examination and laboratory evaluation child turned out to be SCARMD. Hence this case report emphasizes that suspicion of SCARMD has to be made when female children presented with features of DMD, and genetic counselling and prenatal diagnosis should be done to reduce the burden of the disease in the community.
\end{abstract}

Keywords: Muscular dystrophy, Sarcoglycanopathy, SCARMD

\section{INTRODUCTION}

SCARMD is a variant of sarcoglycanopathy resulting from mutation in the sarcoglycan genes. There are four sarcoglycan genes and their corresponding proteins, namely alpha, beta, gamma and delta sarcoglycans. ${ }^{1}$ Sarcoglycanopathies are relatively rare progressive muscular dystrophies with autosomal recessive inheritance which belongs to the group of limb girdle muscular dystrophies (LGMD) and are caused by mutation in any one of the four sarcoglycan genes: alpha (LGMD 2D), beta (LGMD 2E), gamma (LGMD 2C) and delta (LGMD 2F). ${ }^{2}$ Patients with primary sarcoglycanopathy are clinically indistinguishable from those with the primary dystrophinopathies. Consecutively, a definitive diagnosis can only be achieved through biochemical and molecular analysis. ${ }^{3}$ SCARMDs are severe form of sarcoglycanopathies. With advances in genetics and immunocytochemistry, most cases of SCARMD are now known to result from mutations of alpha and gamma sarcoglycan gene. ${ }^{4}$

Severe childhood autosomal recessive muscular dystrophy (SCARMD) is characterised by severe DMD like phenotype occurring at early ages and affecting boys as well as girls with similar severity. First report of SCARMD was given by Buss in 1887 and an unequivocal description of transmission and clinical features of SCARMD was given by Kloepfer and Talley in 1958. In 1983, Ben Hamida described signs, symptoms and muscle pathology findings of SCARMD.5 In contrast to dystrophinopathies, sarcoglycanoparhies are characterized by absence of mental retardation and overt cardiac involvement. ${ }^{3}$

\section{CASE REPORT}

A 7-year-old female child $2^{\text {nd }}$ born to $3^{\text {rd }}$ degree consanguineous parents presented with proximal muscle 
weakness beginning in both lower limbs since 4 years of age in the form of difficulty in climbing upstairs, repeated falls while walking and difficulty in getting up from sitting position. Weakness is progressive involving the upper limbs by 7 years of age. She was born full term through normal vaginal delivery at hospital, and her early motor milestones were normal.

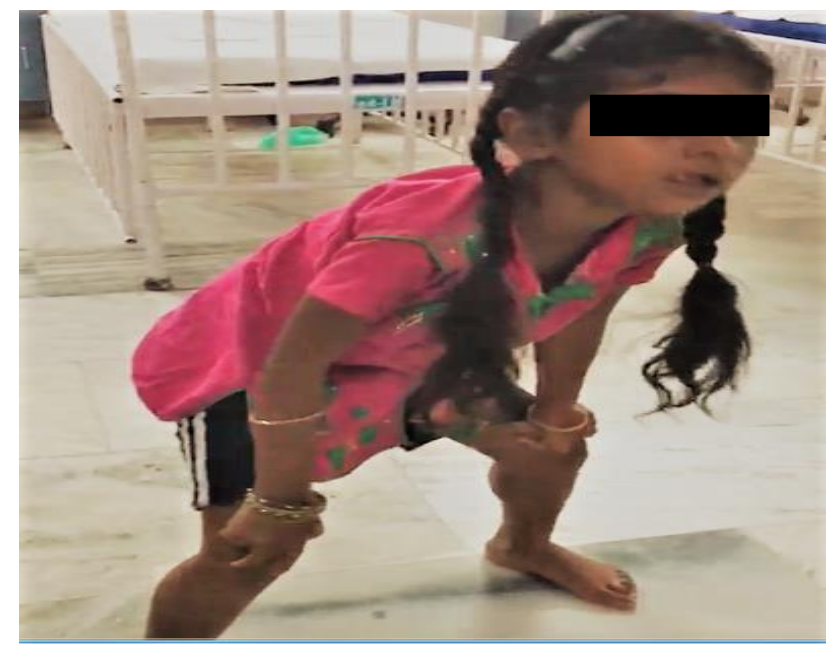

Figure 1: Gower's sign.

On examination, child had severe limb girdle weakness more prominent in lower limbs. Lumbar lordosis, waddling gait were present. Gower's sign was positive (Figure 1). There was pseudohypertrophy of both calves (Figure 2). A clinical diagnosis of muscular dystrophy was made and investigated.

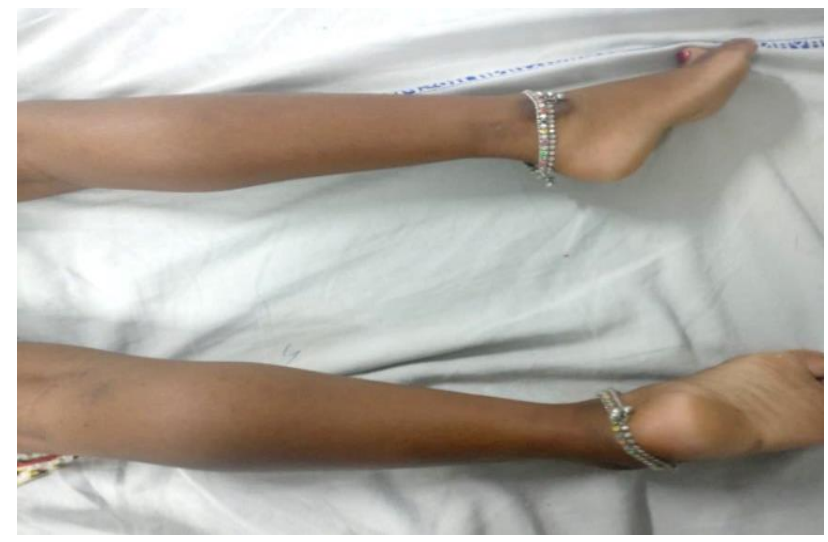

Figure 2: Pseudohypertrophy of calf muscle.

Serum Creatine phosphokinase levels 6995 U/L. Electromyography consistent with myopathic pattern. Muscle biopsy of left quadriceps revealed muscle fiber degeneration, necrosis with hypertrophy and occasional regenerating fibers suggestive of muscular dystrophy. Child evaluated with Immunohistochemistry, showed normal staining pattern for dystrophin. Immunostaining to sarcoglycans shows total absence in all fibers. Mutation of sarcoglycans genes could not be studied due to non-availability. Electrocardiogram and 2-D echocardiogram did not reveal any abnormality of myocardial contractility.

\section{DISCUSSION}

SCARMD was classified separately from dystrophinopathy due to differences in the mode of inheritance. ${ }^{6}$ As this is an autosomal recessive disease, both males and females present with equal severity, which is exceptional for manifesting carrier females of DMD. ${ }^{7}$ Severe childhood autosomal recessive muscular dystrophies are clinically almost indistinguishable from DMD. They are mostly due to mutation in the sarcoglycan genes (alpha, beta, gamma and delta sarcoglycan genes). These genes encode four sarcolemmal proteins that are part of the dystrophin complex. It is therefore not entirely surprising that the phenotype of children with these disorders is so similar to that of children with DMD. ${ }^{7,8}$

However, there are subtle clinical differences that can help to distinguish DMD from SCARMD on clinical grounds. Early motor milestones are typically delayed in DMD, whilst they are normal in children with SCARMD. Whilst, in DMD, children are never able to run or jump, these functional abilities are usually preserved at the beginning in most patients with SCARMD. The distribution of weakness is very similar, but there are some differences. In SCARMD, there is typically more significant scapular winging and weakness, compared to DMD, and more substantial weakness of the hip and trunk extensors with an increased lardotic posture compared to that generally observed in children with DMD. The quadriceps muscle is more affected than the hamstrings in DMD, but the reverse is generally found in SCARMD. ${ }^{8}$ Intelligence is always normal in SCARMD. Cardiac function is usually better preserved in SCARMD than in DMD. ${ }^{3,9}$ The main similarities and differences between DMD and SCARMD are summarized in Table 1.

\section{Table 1: Main clinical features of DMD and SCARMD.}

\begin{tabular}{|c|c|c|}
\hline $\begin{array}{l}\text { Clinical } \\
\text { features }\end{array}$ & DMD & SCARMD \\
\hline Sex distribution & Boys & $\begin{array}{l}\text { Both boys and } \\
\text { girls }\end{array}$ \\
\hline Calf hypertrophy & Common & Common \\
\hline $\begin{array}{l}\text { Weak foot } \\
\text { dorsiflexion }\end{array}$ & Rare & Common \\
\hline Lumbar lordosis & Moderate & Severe \\
\hline $\begin{array}{l}\text { Scapular } \\
\text { winging }\end{array}$ & Mild & $\begin{array}{l}\text { Moderate to } \\
\text { severe }\end{array}$ \\
\hline Intellect & $\begin{array}{l}\text { Mild mental } \\
\text { retardation }\end{array}$ & Normal \\
\hline $\begin{array}{l}\text { Cardiac } \\
\text { involvement }\end{array}$ & Present & Absent \\
\hline $\begin{array}{l}\text { Serum CPK } \\
\text { levels }\end{array}$ & $\begin{array}{l}>10 \text { times of } \\
\text { normal }\end{array}$ & $\begin{array}{l}>10 \text { times of } \\
\text { normal }\end{array}$ \\
\hline
\end{tabular}


Immunohistochemical analysis is the most reliable method of diagnosis. A mutation in single sarcoglycan gene leads to destabilization of entire SG complex and secondary deficiency of other SG proteins.10 As they are interlinked, loss of more than one subunit on the immunostaining is common and immunostaining often proves to be inadequate to know the primary defect. 6 The most frequently reported pattern is that of multiple SG deficiencies in various combinations. Sarcoglycan gene mutation analysis is essential to know the specific diagnosis in such cases with multiple deficiencies. But when dystrophin appears at normal levels or is only slightly decreased in amount and no effect in dystrophin gene is found a diagnosis of SGP is likely. ${ }^{10}$

In this child history, clinical examination findings, EMG and serum CPK levels all are correlating with wellknown Duchene muscular dystrophy which is rarely possible in female child. DMD like phenotype in a female child can be explained by (a) Lyon hypothesis (in which the normal $\mathrm{X}$-chromosome become inactivated and the $\mathrm{X}$-chromosome with mutation is expressed. ${ }^{11,12}(\mathrm{~b})$ Female child with Turner syndrome, 45X0. Because of presence of only one X-chromosome mutation in that will manifest as DMD. ${ }^{12,13} \quad$ (c) Sarcoglycanopathies (sarcoglycanopathies that are inherited by autosomal recessive pattern thus affects boys as well as girls). ${ }^{5,7}$

On clinical examination there is no features of Turners syndrome and USG abdomen shows normal ovaries and uterus, thus turners syndrome ruled out. Usually boys with DMD also have mental subnormality and cardiac involvement due to lack of dystrophin in brain and cardiac muscle cells which is not present in this child. A clinical diagnosis of SCARMD was considered and investigated with muscle biopsy and immunocytology showing normal staining pattern for dystrophin. Immunostaining to sarcoglycans shows total absence in all fibers. Mutation of sarcoglycan genes could not be studied due to non-availability.

\section{CONCLUSION}

Sarcoglycanopathy should be considered in a female presenting with early childhood onset, proximal muscle weakness and calf hypertrophy raised CPK levels and myopathic pattern on EMG. Molecular testing, genetic counselling and prenatal diagnosis should be emphasized to reduce the burden of the disease in the community

\footnotetext{
Funding: No funding sources Conflict of interest: None declared

Ethical approval: Not required
}

\section{REFERENCES}

1. Sharma MC, Mannan R, Singh NG, Gulati S, Kalra V, Sarkar C. Sarcoglycanopathies: An enigmatic form of muscular dystrophy-A report of 7 cases. Neurol India. 2004;52(4):446-9.

2. Duggan DJ, Gorospe JR, Fanin M, Hoffman EP, Angelini C, Pegoraro E, et al. Mutations in the sarcoglycan genes in patients with myopathy. New England J Med. 1997;336(9):618-25.

3. Mustafa E, Khandaker MA, Rashid MM, Ghose SK, Salehin M, Hussain AR, et al. Sarcoglycanopathy-a rare case report and literature review. J Dhaka Med Coll. 2014;22(2):232-5.

4. Bushby KM. Making sense of the limb-girdle muscular dystrophies. Brain. 1999 ;122(8):1403-20.

5. Khadilkar Satish V, Menezes Krishe M, Singh Rakesh K, Hegde Madhuri R. Case Report-Severe childhood autosomal recessive muscular dystrophy, mental subnormality and chorea. Neurology India. $2006 ; 54(3): 293-5$

6. Ozawa E, Noguchi S, Mizuno Y, Hagiwara Y, Yoshida M. From dystrophinopathy to sarcoglycanopathy: evolution of a concept of muscular dystrophy. Muscle \& Nerve: Official Journal of the American Association of Electrodiagnostic Medicine. 1998 ;21(4):421-38.

7. Khadilkar SV, Singh RK. Limb girdle muscular dystrophies in India. Neurol India. 2008 ;56(3):281.

8. Emery AE, Muntoni F, Quinlivan RC. Duchenne muscular dystrophy. OUP Oxford; 2015.

9. Kapoor S, Tatke M, Aggarwal S, Gupta A. Betasarcoglycanopathy. Indian J Pediatr. 2005;72(1):714.

10. Gulati S, Leekha S, Sharma MC, Kalra V. Gammasarcoglycanopathy. Indian pediatrics. 2003;40(11):1077-81.

11. Joshi S. Duchenne muscular dystrophy in a female child. Indian Pediatr. 2002;39(1):98.

12. Venugopal V, Pavlakis S. Duchenne Muscular Dystrophy. Stat Pearls. Treasure Island (FL): Statpearls Publishing. 2018.

13. Nahrel R, Kosam A. Duchenne muscular dystrophy in a female child with Turner syndrome: a case report. Int J Med Res Rev. 2014;2.

Cite this article as: Rafi SM, Sreekantha SS, Tumati KR. Female child presenting with Duchenne muscular dystrophy like phenotype: severe childhood autosomal recessive muscular dystrophy: a rare case report. Int J Contemp Pediatr 2019;6:212-4. 